\title{
AKTIVITAS ANTIOKSIDAN DAUN MAGENTA (Peristrophe bivalvis (L.) Merr) SEBAGAI SALAH SATU KANDIDAT PENGOBATAN BAHAN BERBASIS HERBAL SERTA BIOAKTIVITASNYA SEBAGAI ANALGETIK
}

\author{
(ANTIOXIDANT ACTIVITY OF MAGENTA LEAF (Peristrophe bivalvis (L.) Merr) \\ AS A COMPLIMENTARY NATURAL TREATMENT AND ITS BIOACTIVITY AS ANALGETIC)
}

\author{
KETUT AGUS ADRIANTA*• \\ *Program Studi Sarjana Farmasi, Fakultas Farmasi Universitas Mahasaraswati Denpasar \\ Jl. Kamboja No. 11 A, Denpasar Bali
}

\begin{abstract}
Abstrak: Antioksidan merupakan senyawa yang memiliki peran penting dalam menjaga kesehatan karena kemampuannya menangkap molekul radikal bebas. Antioksidan mampu mendonorkan elektron sehingga radikal bebas tidak reaktif. Daun Magenta (Peristrophe bivalvis (L.) Merr) merupakan tanaman yang mudah dijumpai di Indonesia khususnya di Bali. Daun magenta memiliki kandungan metabolit sekunder yang merupakan senyawa yang dapat berfungsi sebagai antioksidan. Untuk itu perlu dilakukan penelitian untuk menguji aktivitas antioksidan dari daun Magenta (Peristrophe bivalvis (L.) Merr ini. Penelitian ini diawali dengan penyiapan sampel berupa ektrak etanol daun Magenta (Peristrophe bivalvis (L.) Merr lalu dimaserasi dengan pelarut etanol 96\%. Kemudian dilakukan pengujian aktivitas antioksidan dengan metode DPPH (1,1Difenil-2-pikrilhidrazil) menggunakan Spektrofotometer UV-Vis pada panjang gelombang $516 \mathrm{~nm}$. Hasil persentase peredaman tersebut diplotkan dalam sebuah kurva regresi linear sehingga diperoleh nilai $\mathrm{IC}_{50}$. Dari hasil pengujian aktivitas antioksidan diperoleh kurva regresi linear dengan persamaan, $y=2,9398 x+3,9518$ dan $\mathrm{R}^{2}=0,9878$ sehingga diperoleh nilai $\mathrm{IC}_{50}$ sebesar $15,675 \mathrm{ppm}$ dan tergolong aktivitas antioksidan yang sangat kuat. Penelitian ini juga menguji bioaktivitas ekstrak etanol daun magenta sebagai analgetik dengan menguji presentase proteksi terhadap paparan dari penginduksi nyeri yaitu asam asetat $1 \%$. Persentase proteksi dari ekstrak daun magenta menunjukkan hasil terbaik pada dosis pemberian $2 \mathrm{~g} / \mathrm{KgBB}$ dengan proses proteksi sebesar: $77,161 \%$.
\end{abstract}

Kata kunci: analgesik, antioksidan, daun magenta (Peristrophe bivalvis (L.) Merr), DPPH (1,1-Difenil-2pikrihidrazil), flavonoid, spektrofotometer UV-Vis

\begin{abstract}
Antioxidants are compounds that have an important role in maintaining health because of their ability to capture free radical molecules. Magenta (Peristrophe bivalvis (L.) Merr) is a plant that is easily found in Indonesia, especially in Bali. Magenta leaves contain secondary metabolites which are compounds that can function as antioxidants. For this reason, it is necessary to conduct research to test the antioxidant activity of the leaves of Magenta (Peristrophe bivalvis (L.) Merr) which grows in the province of Bali so that it can be used as one of the medicinal candidates derived from natural ingredients. This study began with the preparation of samples in the form of ethanol extract of Magenta leaves, then macerated with $96 \%$ ethanol and antioxidant activity was tested by DPPH (1,1-Difenyl-2-pikrilhidrazil). The method using UV-Vis spectrophotometer at a wavelength of $516 \mathrm{~nm}$. Percentage reduction results This is plotted in a linear regression curve so that the $\mathrm{IC}_{50}$ value is obtained. From the results of testing the antioxidant activity obtained a linear regression curve with the equation, $\mathrm{y}=2.9398 \mathrm{x}+3.9518$ and $\mathrm{R}^{2}=0.9878$ so that the $\mathrm{IC}_{50}$ value of $15.675 \mathrm{ppm}$ is obtained. shows that the ethanol extract is in the form of an ethanol extract of the Magenta leaf (Peristrophe bivalvis (L.) Merr) has activity antioxidant which are classified as very strong with $\mathrm{IC}_{50}$ values worth less than $50 \mathrm{ppm}$. In this study also tested the bioactivity of the ethanol extract of the leaves of magenta as an analgesic, by testing the percentage of protection against exposure to acetic acid induction, the percentage of protection from magenta leaf extract showed the best results at a dose of $2 \mathrm{~g} / \mathrm{KgBW}$ with a protection process: $77,161 \%$.
\end{abstract}

Keywords: analgesic, antioxidant, magenta leaves (Peristrophe bivalvis (L.) Merr), DPPH (1,1-Difenil-2pikrihidrazil), flavonoid, UV-Vis spectrophotometer

\footnotetext{
• correspondence email: agusaick@gmail.com
} 


\section{PENDAHULUAN}

Radikal bebas adalah suatu atom yang memiliki satu elektron tidak berpasangan dan bersifat reaktif sehingga cenderung bereaksi terus menerus membentuk radikal yang baru. Radikal bebas sangat berbahaya bagi tubuh manusia karena dapat merusak komponen-komponen sel tubuh seperti lipid, protein, dan DNA (Oktarini, at.al., 2014). Radikal bebas merupakan molekul yang tidak stabil dari luar maupun dalam tubuh yang secara perlahan dapat menimbulkan berbagai penyakit yang mengganggu kesehatan. Untuk menangani radikal bebas, dapat digunakan zat antioksidan yang dapat diperoleh baik dari tanaman maupun hewan. Antioksidan adalah senyawa yang memiliki peran penting dalam menjaga kesehatan karena kemampuannya menangkap molekul radikal bebas. Kemampuan untuk menghambat reaksi oksidatif dalam tubuh yang merupakan penyebab berbagai penyakit (Ardawiah, et.al., 2015). Penggunaan obat tradisional di Indonesia sudah berlangsung sejak ribuan tahun yang lalu, sebelum obat modern ditemukan dan dipasarkan. Hal itu tercermin antara lain pada lukisan di relief Candi Borobudur dan resep tanaman obat yang ditulis dari tahun 991 sampai 1016 pada daun lontar di Bali (Purwaningsih, 2013). Tanaman magenta (Peristrophe bivalvis (L.) Merr) merupakan tanaman semak yang banyak tumbuh di kawasan Asia khususnya Asia Tenggara (Jawa, Indonesia). Tanaman ini adalah tanaman herba tahunan yang tersebar secara luas di daerah iklim sejuk dan lembab. Tinggi tanaman berkisar 50-150 cm, batang persegi panjang berwarna coklat kehijauan. Daun berbentuk bulat telur dengan panjang 7-10 $\mathrm{cm}$ yang berwarna hijau. Bunga tunggal berkelopak dua, berdasarkan warna bunga, tanaman ini dibedakan dalam empat varietas yang berwarna ungu, ungu-magenta, merah, dan kuning (Emilio et al., 2017). Senyawa yang ditemukan dalam daun tanaman magenta antara lain minyak esensial, minyak lemak, saponin, sapofonin, tanin, flavonoid, tinggi antosianin, tinggi total kandungan fenolik yang diikuti dengan tingginya kapasistas antioksidan pada daun tanaman magenta.

Pada penelitian yang dilakukan oleh Nguyen et al (2016), ekstrak daun tanaman magenta yang menggunakan pelarut organik (etanol) menunjukan aktivitas antioksidan melalui penghambatan DPPH yang lebih tinggi dari 50\% (Nguyen et al., 2016). Dalam penelitian ini digunakan pelarut etanol $96 \%$ karena etanol bersifat polar dan tidak beracun sehingga aman digunakan sebagai pelarut pada bahan pangan (Moeksin dan Ronald, 2009).

Pengujian aktivitas antioksidan ekstrak etanol magenta (Peristrophe bivalvis (L.) Merr) dilakukan dengan menggunakan metode 1,1diphenyl-2-picrylhidrazil (DPPH). Pengujian dengan metode ini dinyatakan pada konsentrasi inhibisi (inhibition consentration) atau $\mathrm{IC}_{50}$ (Shivaprasad dkk, 2005 dalam Mailandari, 2012). Nilai IC $_{50}$ yang semakin kecil menunjukkan semakin tingginya aktivitas antioksidan. Metode ini merupakan metode pengujian antioksidan yang sederhana, cepat serta tidak membutuhkan banyak reagen seperti uji lainnya (Mailandari, 2012).

Pengujian efektivitas analgesik ekstrak etanol daun magenta dilakukan dengan menggunakan 4 perlakuan: P1 adalah kelompok placebo, P2 adalah kelompok pemberian paracetamol $65 \mathrm{mg} / \mathrm{KgBB}, \mathrm{P} 3$ adalah kelompok pemberian ekstrak etanol daun magenta $2 \mathrm{~g} / \mathrm{KgBB}$ dan $\mathrm{P} 4$ adalah kelompok pemberian ekstrak etanol daun magenta $4 \mathrm{~g} / \mathrm{KgBB}$ dengan penginduksi adalah asam asetat $1 \%$ secara Intramuskuler.

\section{METODE PENELITIAN}

\section{Rangcangan Penelitian Uji aktivitas} Antioksidan. Jenis penelitian yang dilakukan adalah penelitian eksperimental yang dilakukan di Laboratorium Fakultas Farmasi Saraswati Denpasar, dan Laboratorium Biomedik Universitas Udayana. Penelitian eksperimental sebagai metode penelitian yang digunakan untuk mencari pengaruh perlakuan tertentu terhadap yang lain dalam kondisi yang terkendalikan.

Adapun teknik sampling yang digunakan dalam penelitian ini adalah non probability sampling (random). Pada pengambilan sampel random, setiap unit populasi mempunyai kesempatan yang sama untuk diambil sebagai sampel.

\section{Rancangan Penelitian Uji Bioaktivitas Analgetik. Jenis rancangan penelitian uji bioaktivitas analgesik adalah eksperimental murni dengan rancangan penelitian post-test only randomized control group design.}

Bahan. Bahan-bahan yang digunakan dalam penelitian yaitu Daun magenta (Peristrophe bivalvis (L.) Merr), etanol 96\%, DPPH (2,2difenil-1-pikrilhidrazil), Asam asetat, etanol 80\%, parasetamol, 
Metode Uji Aktivitas Antioksidan. Adapun metode atau alur kerja dari penelitian ini adalah sebagai berikut:

1. Pembuatan Ekstrak

a) Serbuk daun magenta (Peristrophe bivalvis (L.) Merr) ditimbang sebanyak 250 gram dan dimasukkan ke dalam toples.

b) Tambahkan dengan pelarut etanol $96 \%$, jumlah bahan dan campuran pelarut berbanding $1: 7(\mathrm{~b} / \mathrm{v})$, diaduk konstan selama 10 menit kemudian tolpes kaca ditutup dengan aluminium foil lalu dibungkus dengan plastik wrap.

c) Setelah 2 x 24 jam, toples dibuka lalu diaduk konstan dengan batang pengaduk selama 15 menit. Setelah diaduk, disaring dengan corong Buchner.

d) Filtrat dimasukkan ke dalam toples kaca yang berbeda, lalu ditutup rapat dengan aluminium foil dan dibungkus dengan plastik wrap. Toples disimpan pada tempat yang terhindar dari cahaya matahari.

e) Maserat sisa filtrasi dimasukkan ke dalam toples awal, lalu ditambahkan pelarut etanol 96\%, diaduk konstan dengan batang pengaduk selama 10 menit, lalu tutup rapat dengan aluminium foil lalu dibungkus dengan plastik wrap. Toples disimpan pada tempat yang terhindar dari cahaya matahari. Ulangi proses maserasi ini untuk 24 jam berikutnya agar tahapan maserasi dilakukan selama 3 × 24 jam.

f) Setelah dimaserasi $3 \times 24$ jam, seluruh filtrat dijadikan satu, lalu dilakukan penyaringan kembali. Setelah disaring, filtrat dihitung berapa volume totalnya.

g) Filtrat dipekatkan dengan rotary evaporator pada suhu $40^{\circ} \mathrm{C}$ untuk menguapkan pelarut sehingga didapat filtrat kental. Ini dilakukan sampai filtrat yang di evaporasi tersisa sekitar $100 \mathrm{ml}$ agar mudah dikeluarkan dari labu evaporator.

h) Sisa filtrat kemudian dipekatkan kembali pada waterbath dengan suhu $40^{\circ} \mathrm{C}$ sampai di dapat ekstrak kental dan pekat.

2. Pengujian Aktivitas Antioksidan

a) Pembuatan larutan sampel induk $50 \mathrm{ppm}$ Ekstrak etanol magenta (Peristrophe bivalvis (L.) Merr) hasil maserasi dibuat larutan sampel induk pada konsentrasi 50 ppm dengan menimbang $5 \mathrm{mg}$ ekstrak kental lalu dimasukkan kedalam labu tentukur $100 \mathrm{ml}$ kemudian dilarutkan dengan etanol 96\% sampai tanda batas dan dikocok hingga homogen.

b) Pembuatan larutan sampel uji

Dari larutan sampel induk $50 \mathrm{ppm}$ kemudian diencerkan untuk membuat lima larutan sampel uji masing-masing dengan konsentrasi $2 ; 4 ; 6 ; 8 ; 10$ ppm.

c) Pembuatan larutan baku induk DPPH 100 ppm

Dibuat konsentrasi larutan baku DPPH 100 ppm dengan menimbang $10 \mathrm{mg}$ serbuk DPPH dimasukkan kedalam labu tentukur $100 \mathrm{ml}$ lalu dilarutkan dengan etanol 96\% sampai tanda batas dan dikocok hingga homogen.

d) Pembuatan larutan baku kerja DPPH 40 ppm

Dibuat konsentrasi larutan DPPH 40 ppm dengan cara dipipet sebanyak $40 \mathrm{ml}$ larutan DPPH 100 ppm kemudian dimasukkan kedalam labu tentukur $100 \mathrm{ml}$ lalu dilarutkan dengan etanol $96 \%$ sampai tanda batas dan dikocok hingga homogen.

e) Penentuan Panjang Gelombang Maksimum

Larutan DPPH 40 ppm dipipet sebanyak 4 $\mathrm{ml}$ lalu diukur dengan dengan Spektrofotometer UV-Vis dan diamati absorbansinya pada panjang gelombang 400-800 nm. Dari spektrum ditentukan panjang gelombang maksimum.

f) Pengukuran aktivitas peredaman radikal DPPH denganspektrofotometer UV-Vis

Larutan uji yang berbeda konsentrasi kemudian dipipet masing-masing sebanyak $2 \mathrm{ml}$ dan dimasukkan kedalam enam tabung reaksi yang berbeda kemudian ditambahkan $2 \mathrm{ml}$ DPPH. Sebagai pembanding, pada tabung reaksi yang berbeda larutan DPPH 40 ppm dipipet sebanyak $2 \mathrm{ml}$ kemudian ditambahkan $2 \mathrm{ml}$ etanol 96\%. Seluruh tabung reaksi dikocok dan didiamkan selama 30 menit. Setelah itu diamati absorbansinya pada panjang gelombang maksimum $516 \quad \mathrm{~nm}$ dengan spektrofotometer UV-Vis seluruh hasil yang diperoleh dicatat.

g) Penentuan nilai $\mathrm{IC}_{50}$ dan pembuatan kurva kalibrasi

Dari masing-masing tingkat konsentrasi yang diuji lalu dihitung persentase peredaman kemudian hasil persentase peredaman tersebut diplotkan dalam sebuah grafik sehingga didapat suatu 
persamaan $\mathrm{y}=\mathrm{bx}+\mathrm{a}$ dan akan diperoleh nilai $\mathrm{IC}_{50}$ dengan mengganti $\mathrm{y}=50$ pada persamaan regresi linier dimana $\mathrm{x}$ adalah konsentrasi $(\mu \mathrm{g} / \mathrm{ml})$ dan $\mathrm{y}$ adalah persentase inhibisi (Novita Sari, 2014).

Hasil terhadap uji aktivitas antioksidan yang dilakukan selanjutnya dilakukan uji bioaktivitas terhadap efek analgesik dari ekstrak etanol daun magenta ini.

\section{Metode Uji Efektivitas Analgesik}

1. Kelompok kontrol negatif: Pengamatan/observasi berapa jumlah geliat mencit dalam waktu 20 menit dengan interval waktu pengamatan adalah 5 menit dilihat dari geliat pertama muncut setalah pemberian asam asetat $1 \%$ sebanyak $0,05 \mathrm{ml}$ secara i.p

2. Kelompok kontrol positif: Pengamatan/observasi berapa jumlah geliat mencit dalam waktu 20 menit dengan interval waktu pengamatan adalah 5 menit dilihat dari geliat pertama muncut setalah pemberian asam asetat $1 \%$ sebanyak $0,05 \mathrm{ml}$ secara i.p

3. Kelompok perlakuan 1: Pengamatan/observasi berapa jumlah geliat mencit dalam waktu 20 menit dengan interval waktu pengamatan adalah 5 menit dilihat dari geliat pertama muncut setalah pemberian asam asetat $1 \%$ sebanyak 0,05 ml secara i.p

4. Kelompok perlakuan 2: Pengamatan/observasi berapa jumlah geliat mencit dalam waktu 20 menit dengan interval waktu pengamatan adalah 5 menit dilihat dari geliat pertama muncut setalah pemberian asam asetat $1 \%$ sebanyak 0,05 ml secara i.p

Diamati dan dicatat jumlah geliat yang ditunjukan oleh tiap mencit tiap 5 menit selama 20 menit. Nilai persen proteksi nyeri pada masingmasing kelompok dosis dihitung dengan menggunakan rumus:

$\%$ Proteksi $=\left(100-\frac{(\text { eksperimen } \times 100)}{\text { kontrol perlakuan satu }} \%\right)$

Keterangan:

Ekperimen : jumlah geliat komulatif kelompok percobaan tiap individu

Kontrol : jumlah geliat komulatif kelompok kontrol perlakuan satu rata-rata

\section{HASIL}

\section{Hasil Penentuan Panjang Gelombang Maksimum}

Pengujian aktivitas antioksidan dilakukan dengan mengukur absorbansi larutan pereaksi DPPH pada panjang gelombang maksimum. Panjang gelombang maksimum yang diperoleh yaitu $516 \mathrm{~nm}$ dengan nilai absorbansi 0,786. Selanjutnya, semua pengukuran dengan metode peredaman radikal DPPH dilakukan dengan panjang gelombang $516 \mathrm{~nm}$.

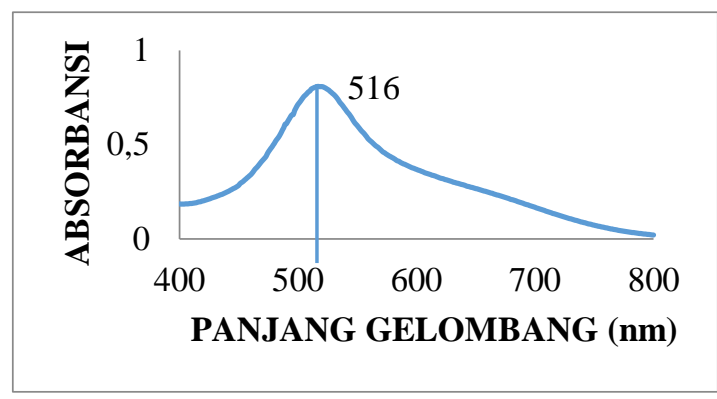

\section{Gambar 1. Spektrum Serapan DPPH pada Panjang Gelombang 400-800 nm}

\section{Pengujian Aktivitas Antioksidan}

Pengujian aktivitas antioksidan ekstrak etanol magenta (Peristrophe bivalvis (L.) Merr) dilakukan dengan menggunakan metode DPPH. Prinsip kerja dari pengukuran ini adalah adanya radikal bebas yaitu DPPH yang dicampurkan dengan senyawa antioksidan yang memiliki kemampuan mendonorkan hidrogen sehingga radikal bebas dapat diredam. DPPH direaksikan dengan larutan uji yang ditandai perubahan warna ungu menjadi kuning. Dari pengujian absorbansi larutan DPPH tanpa penambahan ekstrak etanol Daun Magenta (Peristrophe bivalvis (L.) Merr) dengan metode DPPH diperoleh hasil absorbansi larutan baku DPPH 40 ppm yaitu 0,786. Hasil pengujian absorbansi pada lima konsentrasi ekstrak etanol etanol Daun Magenta yang ditambahkan larutan DPPH antara lain: $2 \mathrm{ppm}=0,377 ; 4 \mathrm{ppm}=$ 0,$35 ; 6 \mathrm{ppm}=0,322 ; 8 \mathrm{ppm}=0,296 ; 10 \mathrm{ppm}=$ 0,282

\section{Perhitungan Persentase Peredaman}

Dari hasil absorbansi larutan uji yang diperoleh dapat dihitung persentase peredaman sebagai berikut:

Diketahui:

Absorbansi DPPH 20 ppm (Baku): 0,415

Absorbansi Larutan sampel 2 ppm + DPPH: 0,377

Absorbansi Larutan sampel 4 ppm + DPPH: 0,350

Absorbansi Larutan sampel 6 ppm + DPPH: 0,322 
Absorbansi Larutan sampel 8 ppm + DPPH: 0,296 Absorbansi Larutan sampel 10 ppm + DPPH: 0,282

Hitung:

Pada kosentrasi 2 ppm:

$\%$ peredaman $=$

$\frac{\text { Absorbansi DPPH - Absorbansi sampel }}{\text { Absorbasi DPPH }} \times 100 \%$

$\%$ peredaman $=\frac{0,415-0,377}{0,415} \times 100 \%$

Dengan cara yang sama dilakukan perhitungan pada konsentrasi 2, 4,6, 8, dan $10 \mathrm{ppm}$, kemudian diperoleh hasil persentase peredaman sebesar $15,66 \%$; 22,41\%; 28,68\%; 32,05\%. Berdasarkan hasil persentase peredaman DPPH pada masing-,masing konsentrasi dapat diketahui bahwa persentase peredaman masing-masing konsentrasi semakin meningkat. Semakin besar konsentrasi larutan sampel uji yang digunakan maka persentase peredaman semakin tinggi artinya semakin banyak antioksidan yang terdapat pada larutan sampel uji maka semakin besar peredaman radikal bebas ditandai dengan meningkatnya persentase peredaman radikal bebas.

\section{Perhitungan Nilai IC $_{50}$}

Dari persentase peredaman dibuat kurva regresi linear sebagai berikut:

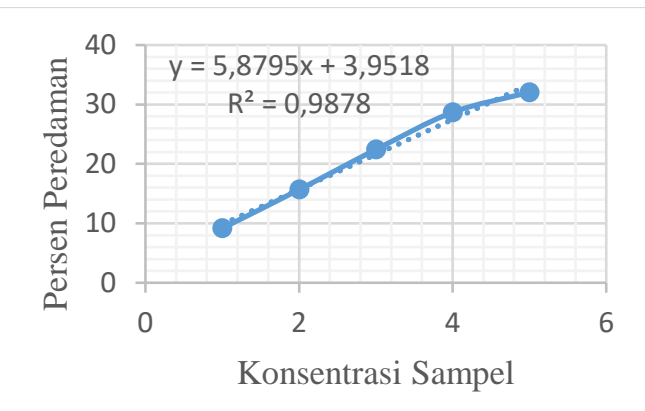

\section{Gambar 2. Kurva Regresi Linear}

Dari kurva regresi, diperoleh persamaan y $=$ $5,8795 x+3,9518$ dan $R^{2}=0,9878$. Dari persamaan ini, akan diperoleh nilai $\mathrm{IC}_{50}$ dengan mengganti $\mathrm{y}=$ 50 pada persamaan regresi linier dimana y adalah persentase inhibisi dan $\mathrm{x}$ adalah konsentrasi dari ekstrak yang akan dicari nilainya, dimana nilai dari $\mathrm{x}$ yang didapat merupakan besarnya konsentrasi yang diperlukan untuk dapat meredam 50\% aktivitas radikal DPPH. Dilihat dari nilai $\mathrm{R}^{2}$ (koefisien determinasi) sebesar 0,9878 menunjukkan bahwa 98,78\% derajat penghambatan dipengaruhi oleh konsentrasi ekstrak etanol etanol Daun Magenta sedangkan kurang dari $2 \%$ dipengaruhi oleh faktor-faktor lain seperti kurang ketelitian dalam penimbangan dan pemipetan yang dilakukan peneliti serta adanya pengotor pada larutan.

$\mathrm{IC}_{50}$ (Inhibition Concentration) adalah bilangan yang menunjukkan konsentrasi ekstrak yang mampu menghambat proses oksidasi sebesar $50 \%$. Nilai $\mathrm{IC}_{50}$ yang semakin kecil menunjukkan semakin tingginya aktivitas antioksidan.Secara spesifik, suatu senyawa dikatakan sebagai antioksidan sangat kuat jika nilai $\mathrm{IC}_{50}$ kurang dari $50 \mathrm{ppm}$, kuat untuk $\mathrm{IC}_{50}$ bernilai $50-100 \mathrm{ppm}$, sedang jika $\mathrm{IC}_{50}$ bernilai $100-150 \mathrm{ppm}$ dan lemah jika $\mathrm{IC}_{50}$ bernilai 151-200 ppm (Supiyanti, dkk., 2010 dalam Wulandari, 2013). Hal ini menunjukan aktivitas antioksidan dalam magenta (Peristrophe bivalvis (L.) Merr) tergolong sangat kuat, karena nilai $\mathrm{IC}_{50}$ ekstrak Daun Magenta (Peristrophe bivalvis (L.) Merr) ketan hitam kurang dari 50 ppm yaitu sebesar 15,68 ppm.

\section{Hasil Perhitungan Pengujian Analgesik}

Tabel 1. Rata-Rata Jumlah Geliat Tiap Kelompok Tiap 5 Menit Selama 20 Menit

\begin{tabular}{ccccc}
\hline \multirow{2}{*}{$\begin{array}{c}\text { Kelom } \\
\text { pok }\end{array}$} & \multicolumn{4}{c}{ Menit } \\
\cline { 2 - 5 } I & $25.00 \pm 6$ & $31.40 \pm 9$ & $28.40 \pm 9$ & $32.40 \pm 1$ \\
& .78 & .31 & .18 & 4.63 \\
II & $27.80 \pm 2$ & $23.40 \pm 4$ & $19.40 \pm 4$ & $15.40 \pm 3$. \\
& .48 & .61 & .15 & 97 \\
III & $25.60 \pm 6$ & $16.80 \pm 3$ & $10.80 \pm 3$ & $7.40 \pm 2.7$ \\
& .06 & .34 & .03 & 9 \\
IV & $29.80 \pm 2$ & $22.80 \pm 1$ & $16.00 \pm 1$ & $12.00 \pm 2$. \\
& .94 & .30 & .73 & 34 \\
\hline
\end{tabular}

Tabel 2. Jumlah Geliat Akhir Masing-Masing Kelompok pada Menit ke-20

\begin{tabular}{ccccc}
\hline Mencit & \multicolumn{4}{c}{ Kelompok Kontrol Perlakuan } \\
\cline { 2 - 5 } Nomor & P1 & P2 & P3 & P4 \\
\hline 1 & 21 & 13 & 6 & 13 \\
2 & 37 & 14 & 6 & 14 \\
3 & 22 & 16 & 5 & 13 \\
4 & 56 & 22 & 8 & 12 \\
5 & 26 & 12 & 12 & 13 \\
$\bar{X}$ & $32.40 \pm$ & $15.40 \pm$ & $7.40 \pm 2$. & $12.00 \pm$ \\
& 14.63 & 3.97 & 79 & 2.34 \\
\hline
\end{tabular}

Keterangan:

$\overline{\mathrm{X}} \quad$ : Rata-rata \pm SD

P1 : Kontrol negatif

P2 : Kontrol Positif

P3 : Ekstrak etanol daun magenta dosis $2 \mathrm{~g} / \mathrm{KgBB}$

P4 : Ekstrak etanol daun magenta dosis $4 \mathrm{~g} / \mathrm{KgBB}$ 


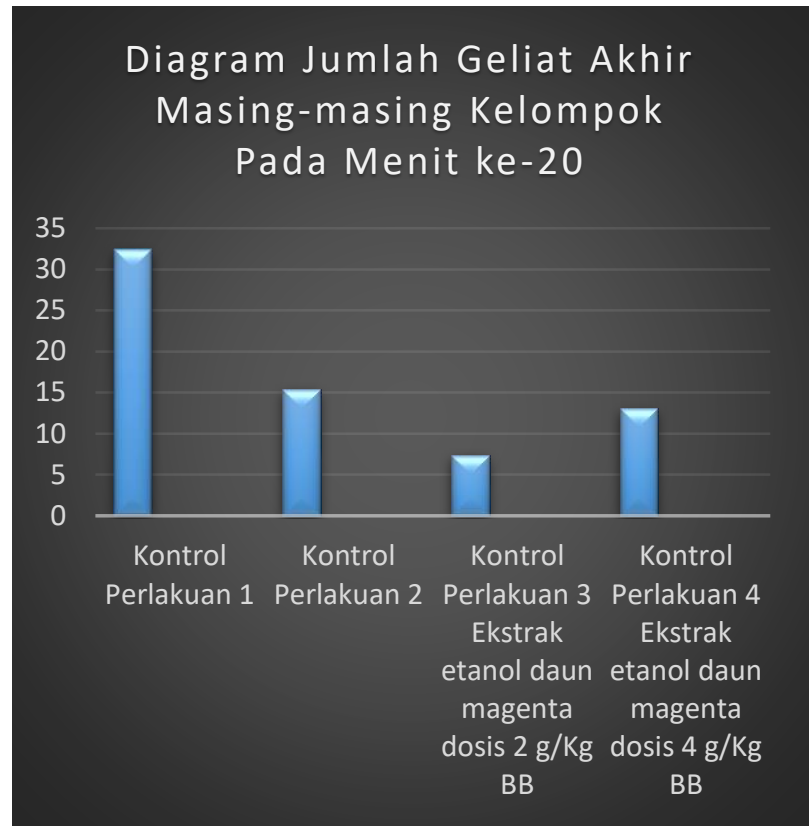

Gambar 3. Diagram Jumlah Geliat Akhir MasingMasing Kelompok pada Menit ke-20

\section{Hasil Pengujian Post Hoc Tukey}

1. Hasil uji antar kelompok kontrol perlakuan 1 dan kelompok kontrol perlakuan 2 dengan nilai $\mathrm{p}=0.015$ dengan interpretasi jika nilai $\mathrm{p}<$ $(0,05)$ menunjukan bahwa kelompok kontrol perlakuan 1 dan kelompok kontrol perlakuan 2 memiliki perbedaan bermakna.

2. Hasil uji antar kelompok kontrol perlakuan 1 dan kelompok kontrol perlakuan 3 dengan nilai $\mathrm{p}=0.001$ dengan interpretasi jika nilai $\mathrm{p}<$ $(0,05)$ menunjukan bahwa kelompok kontrol perlakuan 1 dan kelompok kontrol perlakuan 3 memiliki perbedaan bermakna.

3. Hasil uji antar kelompok kontrol perlakuan 1 dan kelompok kontrol perlakuan 4 dengan nilai $\mathrm{p}=0.005$ dengan interpretasi jika nilai $\mathrm{p}<$ $(0,05)$ menunjukan bahwa kelompok kontrol perlakuan 2 dan kelompok kontrol perlakuan 4 memiliki perbedaan bermakna.

4. Hasil uji antar kelompok kontrol perlakuan 2 dan kelompok kontrol perlakuan 3 dengan nilai $\mathrm{p}=0.386$ dengan interpretasi jika nilai $\mathrm{p}<$ $(0,05)$ menunjukan bahwa kelompok kontrol perlakuan 2 dan kelompok kontrol perlakuan 3 memiliki perbedaan bermakna.

5. Hasil uji antar kelompok kontrol perlakuan 2 dan kelompok kontrol perlakuan 4 dengan nilai $\mathrm{p}=0.960$ dengan interpretasi jika nilai $\mathrm{p}>$ $(0,05)$ menunjukan bahwa kelompok kontrol perlakuan 2 dan kontrol perlakuan 4 tidak memiliki perbedaan bermakna.

6. Hasil uji antar kelompok kontrol perlakuan 3 dan kelompok kontrol perlakuan 4 dengan nilai $\mathrm{p}=0.667$ dengan interpretasi jika nilai $\mathrm{p}>$ $(0,05)$ menunjukan bahwa kelompok kontrol perlakuan 3 dan kontrol perlakuan 4 tidak memiliki perbedaan bermakna.

\section{Persentase Proteksi}

$\%$ Proteksi $=\left(100-\frac{(\text { eksperimen } x 100)}{\text { kontrol perlakuan satu }} \%\right)$

Keterangan:

Ekperimen : jumlah rata-rata geliat komulatif kelompok percobaan

Kontrol : jumlah rata-rata geliat komulatif kelompok kontrol perlakuan satu

a. Kelompok kontrol perlakuan 2:

$\%$ Proteksi $=\left(100-\frac{(15,4 \times 100)}{32,4} \%\right)=$ $52,47 \%$

b. Kelompok kontrol perlakuan 3 ekstrak daun magenta dosis $2 \mathrm{~g} / \mathrm{Kg} \mathrm{BB}$ :

$$
\% \text { Proteksi }=\left(100-\frac{(7,4 \times 100)}{32,4} \%\right) \quad=
$$$$
77,161 \%
$$

c. Kelompok kontrol perlakuan 4 ekstrak daun magenta dosis $4 \mathrm{~g} / \mathrm{Kg} \mathrm{BB}$ :

$$
\begin{aligned}
& \text { \%Proteksi }=\left(100-\frac{(13 \times 100)}{32,4} \%\right)= \\
& 59,877 \%
\end{aligned}
$$

\section{PEMBAHASAN}

Analgesik merupakan kelompok obat yang memiliki aktvitas menekan atau mengurangi rasa nyeri. Efek ini dapat dicapai dengan berbagai cara: menekan kepekaan reseptor nyeri terhadap ransangan mekanik, termik, listrik atau kimiawi dipusat atau perifer atau dengan cara menghambat pembentukan pronstaglandin sebagai mediator sensasi nyeri.

\section{KESIMPULAN}

Ekstrak etanol magenta (Peristrophe bivalvis (L.) Merr) memiliki nilai $\mathrm{IC}_{50}$ sebesar 15,68 ppm yang tergolong antioksidan sangat kuat, dan memiliki potensi sebagai analgetik dengan \% proteksi tebaik sebesar $77,161 \%$ adalah ekstrak dengan dosis $2 \mathrm{~g} / \mathrm{KgBB}$. Asetominofen atau paracetamol bekerja dengan cara hanya menghambat sintesis prostaglandin secara lemah dan tidak mempunyai efek pada agregasi platelet. Asetamenofen juga memiliki sifat analgesik dan antipiretik yang sama untuk NSAID, tetapi bertentangan dengan mereka, itu tidak memiliki aktivitas anti-peradangan apa pun. 
Kandungan flavonoid pada ekstrak etanol daun magenta (Peristrophe bivalvis (L.) Merr) diduga bekerja hampir sama dengan parasetamol yaitu menghambat jalur COX secara reversibel dengan mencegah pertemuan asam arakidonat dengan tempat aktif enzim COX sehingga biosintesis prostaglandin dapat dihambat sehingga respon nyeri tidak diterima oleh saraf dan rasa nyeri yang diakibatkan oleh asam asetat $1 \%$ berkurang tanpa menghilangkan kesadaran.

\section{DAFTAR PUSTAKA}

Irmawati, 2014, Keajaiban Antioksidan, Padi, Jakarta Timur, Indonesia.

Mailandari M., 2012, 'Uji aktivitas Antioksidan Ekstrak Daun Garciniab kydia Roxb. Dengan Metode DPPH dan Identifikasi Senyawa Kimia Fraksi yang Aktif', Depok, Fakultas Matematika dan Ilmu Pengetahuan Alam Program Studi Ekstraksi Farmasi Universitas Indonesia.
Nailufar, A.M., Basito, Anam C., 2012, 'Kajian Karakteristik Beras Ketan Hitam (Oryza Sativa Glutinoas)pada Beberapa Jenis PengemasSelama Penyimpanan' Jurnal.

Novita Sari, Y. 2014, 'Uji Aktivitas Antioksidan Ekstrak Etanol Rimpang Kunyit Putih (Curcuma Mangga Valento \& Zijp) Dengan Metode Dpph (1,1-Difenil-2-Pikrilhidrazil)', D-III Akademi Farmasi Saraswati, Denpasar.

Ridho, E. 2013, 'Uji Aktivitas Antioksidan Ekstrak Metanol Buah Lakum (Cayratia Trifolia) Dengan Metode Dpph (2,2-Difenil-1Pikrilhidrazil)', D-III, Universitas Tanjungpura, Pontianak.

Rosdiana Moeksin, Stevanus Ronald. 2009, Pengaruh Kondisi, Perlakuan Dan Berat Sampel Terhadap Ekstraksi Antosianin Dari Kelopak Bunga Rosela Dengan Pelarut Aquadest Dan Etanol, Jurusan Teknik Kimia Fakultas Teknik Universitas Sriwijaya, Jurnal Teknik Kimia No. 4, Vol. 16. 